\title{
Measurement of Phase-Contrast MRI mitral flow and lateral wall motion for Assessment of Diastolic Function in a Normal Collective
}

\author{
Liane Kecker*, Stephanie Lehrke, Dirk Lossnitzer, Grigorios Korosoglou, Evangelos Giannitsis, Hugo A Katus, \\ Henning Steen
}

From 2011 SCMR/Euro CMR Joint Scientific Sessions

Nice, France. 3-6 February 2011

\section{Introduction}

In approx. $50 \%$ of cases, heart failure is caused by an isolated diastolic dysfunction (DD) in the presence of a preserved systolic function but with comparably devastating outcome. Among others, echocardiography (EC) categorized DD mainly according to early (E-wave) and late (A-wave) diastolic mitral blood flow (MBF) as well as tissue-doppler imaging (TDI) showing characteristic $S^{`}-E^{\prime}-A^{\prime}$ lateral wall velocity patterns.

Cardiovascular magnetic resonance (CMR) has excellent capabilities to assess blood flow and myocardial tissue motion using phase contrast (PC-CMR) imaging but has not been used to quantify DD similar to the EC approach.

\section{Purpose}

We introduce TDI-comparable tissue-phase-contrast imaging (TPCI) of the lateral wall and present reference values for MBF and TPCI in a normal collective.

\section{Material and methods}

In 120 male/female healthy volunteers divided into three age groups $(1=20-35 y s ; 2=36-50 y s . ; 3=>51 \mathrm{ys}) \mathrm{MBF}$ and TPCI was measured by single-slice short axis PC-CMR (60phases, velocity-encoding $=100 \mathrm{~cm} / \mathrm{s}$ ) comparable to typical EC locations at the tip of mitral leaflets in diastole on a $1.5 \mathrm{~T}$ whole body MRI system (Philips Achieva). Similar to EC, mitral E-and A-waves, lateral $S^{\prime}$-E'-A-velocities, E/A-, E'/A'- and E/E'-ratios were calculated and compared using ANOVA statistics $(\mathrm{p}<0.05=$ significant $)$.

University Heidelberg, Heidelberg, Germany

\section{Results}

From group 1 to 3, for MBF there is a significant Ewave decrease, A-wave increase and E-A ratio decrease $(\mathrm{p}<0.05)$. Similarly albeit not significant for TPCI, we measured an $S^{\prime}$-and $E^{\prime}$-wave decrease but $A^{\prime}$-wave increase. The E'/A' ratio decreased significantly $(\mathrm{p}=0.04)$ whereas $E / \mathrm{E}^{`}$ remained unchanged for groups 1-3 (figure 1). Mean scan-time was $2.40 \pm 1.12 \mathrm{~min}$, mean analysis time was $3.00 \pm 1.2 \mathrm{~min}$.

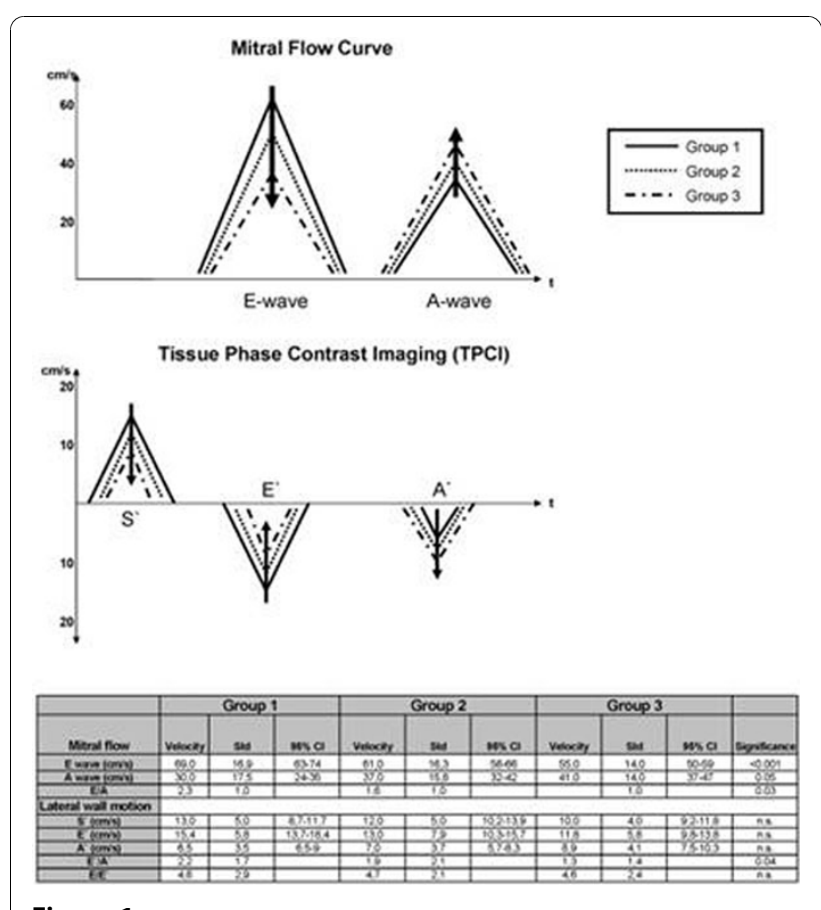

Figure 1

(c) 2011 Kecker et al; licensee BioMed Central Ltd. This is an open access article distributed under the terms of the Creative Commons :HW Central Attribution License (http://creativecommons.org/licenses/by/2.0), which permits unrestricted use, distribution, and reproduction in any medium, provided the original work is properly cited. 


\section{Conclusion}

By applying PC-CMR to a normal collective we showed for the first time that TPCI is feasible and can be utilized for evaluation of DD similar to the echocardiography approach in a reasonable scanning and analysis time. The generated reference values for MBF and TPCI could be potentially utilized for future evaluations for DD. However, further studies have to be conducted comparing PC-CMR with conventional EC.

Published: 2 February 2011

doi:10.1186/1532-429X-13-S1-P122

Cite this article as: Kecker et al:: Measurement of Phase-Contrast MRI mitral flow and lateral wall motion for Assessment of Diastolic Function in a Normal Collective. Journal of Cardiovascular Magnetic Resonance 2011 13(Suppl 1):P122.

Submit your next manuscript to BioMed Central and take full advantage of:

- Convenient online submission

- Thorough peer review

- No space constraints or color figure charges

- Immediate publication on acceptance

- Inclusion in PubMed, CAS, Scopus and Google Scholar

- Research which is freely available for redistribution

Submit your manuscript at www.biomedcentral.com/submit 